\title{
Developing Techniques for the Utilization of Planctomycetes As Producers of Bioactive Molecules
}

\author{
Olga Jeske1, Frank Surup2,3, Marcel Ketteniß1', Patrick Rast ${ }^{1}$, Birthe Förster ${ }^{2,3}$, \\ Mareike Jogler ${ }^{1}$, Joachim Wink ${ }^{2}$ and Christian Jogler ${ }^{1 *}$
}

'Department of Microbial Cell Biology and Genetics, Leibniz Institute DSMZ, Braunschweig, Germany, ${ }^{2}$ Department of Microbial Drugs, Helmholtz Centre for Infection Research, Braunschweig, Germany, ${ }^{3}$ German Centre for Infection Research Association, Partner Site Hannover-Braunschweig, Braunschweig, Germany

\section{OPEN ACCESS}

Edited by:

Damien Paul Devos,

Centro Andaluz de Biología del Desarrollo and University of Pablo

Olavide, Sevilla, Spain

Reviewed by:

Marc Strous,

University of Calgary, Canada Olga Lage,

University of Porto, Portugal

*Correspondence:

Christian Jogler christian@jogler.de

Specialty section:

This article was submitted to Evolutionary and Genomic Microbiology,

a section of the journal

Frontiers in Microbiology

Received: 20 April 2016

Accepted: 26 July 2016

Published: 19 August 2016

Citation:

Jeske O, Surup F, Ketteniß $M$,

Rast $P$, Förster $B$, Jogler $M$, Wink J

and Jogler C (2016) Developing

Techniques for the Utilization of Planctomycetes As Producers

of Bioactive Molecules.

Front. Microbiol. 7:1242.

doi: 10.3389/fmicb.2016.01242
Planctomycetes are conspicuous, ubiquitous, environmentally important bacteria. They can attach to various surfaces in aquatic habitats and form biofilms. Their unique FtsZ-independent budding cell division mechanism is associated with slow growth and doubling times from $6 \mathrm{~h}$ up to 1 month. Despite this putative disadvantage in the struggle to colonize surfaces, Planctomycetes are frequently associated with aquatic phototrophic organisms such as diatoms, cyanobacteria or kelp, whereby Planctomycetes can account for up to $50 \%$ of the biofilm-forming bacterial population. Consequently, Planctomycetes were postulated to play an important role in carbon utilization, for example as scavengers after phototrophic blooms. However, given their observed slow growth, such findings are surprising since other faster- growing heterotrophs tend to colonize similar ecological niches. Accordingly, Planctomycetes were suspected to produce antibiotics for habitat protection in response to the attachment on phototrophs. Recently, we demonstrated their genomic potential to produce non-ribosomal peptides, polyketides, bacteriocins, and terpenoids that might have antibiotic activities. In this study, we describe the development of a pipeline that consists of tools and procedures to cultivate Planctomycetes for the production of antimicrobial compounds in a chemically defined medium and a procedure to chemically mimic their interaction with other organisms such as for example cyanobacteria. We evaluated and adjusted screening assays to enable the hunt for planctomycetal antibiotics. As proof of principle, we demonstrate antimicrobial activities of planctomycetal extracts from Planctopirus limnophila DSM 3776, Rhodopirellula baltica DSM 10527, and the recently isolated strain Pan216. By combining UVNis and high resolution mass spectrometry data from high-performance liquid chromatography fractionations with growth inhibition of indicator strains, we were able to assign the antibiotic activity to candidate peaks related to planctomycetal antimicrobial compounds. The MS analysis points toward the production of novel bioactive molecules with novel structures. Consequently, we developed a large scale cultivation procedure to allow future structural elucidation of such compounds. Our findings might have implications for the discovery of novel antibiotics as Planctomycetes represent a yet untapped resource that could be developed by employing the tools and methods described in this study.

Keywords: Planctomycetes, secondary metabolites, screening, antibiotics, natural products, Planctopirus limnophila, Rhodopirellula baltica 


\section{INTRODUCTION}

Antibiotics are mostly small molecules with antimicrobial activity produced by nearly all sorts of living things. They revolutionized treatment of infectious diseases, saving countless lives. The ability to produce such active molecules - mostly as secondary metabolites - is unevenly distributed among different species (Berdy, 2005). In the kingdom of bacteria, Actinomycetes are the best studied producers, followed by Myxobacteria, Cyanobacteria and certain Bacillus- and Pseudomonas strains. In total about 13,800 'active' compounds of bacterial origin are known (Berdy, 2005). However, these 'usual suspects' in terms of antibiotic production have been heavily screened in the past and the discovery of novel lead structures decreased, while rediscovery rates of known compounds increased (Cooper and Shlaes, 2011). Consequently, only four new classes of antibiotics have been brought to market in the past four decades (Cooper and Shlaes, 2011). This falls far short of demand and only 74 years after the first treatment with 'natural' antibiotics, we again face the specter of incurable bacterial infections, now due to multidrug resistant pathogens (Cooper and Shlaes, 2011). To prevent the post-antibiotic era from coming true, the discovery of novel antibiotic structures is key (Fowler et al., 2014). The chances to discover such structures correlate among other factors directly with the phylogenetic distance between the microorganism under study and the already known producers (Müller and Wink, 2014). Thus, phylogenetically distinct bacterial linages might represent a valuable source for novel secondary metabolites. For instance, the candidate phylum 'Tectomicrobia' that dwells in association with a marine sponge was recently found to comprise a distinct and promising metabolic repertoire (Wilson et al., 2014). Besides such phylogenetic aspects, most potent antibiotic producers are characterized by large genomes with often more than $8 \mathrm{MB}$ and complex life styles, involving for example differentiation processes (Müller and Wink, 2014). Employing these criteria, entire bacteria phyla could be judged as putative 'talented' producers if basic knowledge about their ecology, cell biology and genomic architecture is available.

Thus, we screened the literature with a focus on little studied 'conspicuous' bacterial phyla that might represent putative 'talented' producers and identified Planctomycetes as candidates. Firstly, these ubiquitous and environmentally important bacteria possess large genomes (Glöckner et al., 2003; Jeske et al., 2013). Secondly, the planctomycetal cell biology is remarkable and was speculated to parallel eukaryotic cells in some aspects (Fuerst and Sagulenko, 2011). While some of these findings, such as the lack of peptidoglycan cell walls have been recently challenged (Jeske et al., 2015; van Teeseling et al., 2015), other traits like their lifestyle switch after cell division, makes them unique among bacteria. Planctomycetes divide mostly through polar budding rather than binary fission, without employing the otherwise universal bacterial division protein FtsZ (Tekniepe et al., 1981; Pilhofer et al., 2008; Lee et al., 2009; Jogler et al., 2012). In the model organism Planctopirus limnophila for example, cell division is further coupled to a lifestyle switch, since only sessile stalked mother cells can divide. Flagellated, planktonic daughter cells need to develop into stalked, sessile cells prior to division (Gade et al., 2005; Jogler et al., 2011; Jogler and Jogler, 2013). Attached Planctomycetes can form dense biofilms, preferably on the surface of blooming diatoms (Morris et al., 2006; Pizzetti et al., 2011a) and they represent up to $50 \%$ of the bacterial community on Laminaria hyperborea (Bengtsson and Øvreås, 2010). Given the slow growth of Planctomycetes under favorable laboratory conditions, some species have doubling times of up to 1 month (Strous et al., 1998), their abundance in such embattled carbon rich habitats in nature, in contrast to the largely oligotrophic surrounding water, appears counterintuitive (Lage and Bondoso, 2014). Most other heterotrophs that dwell in such ecological niches divide much faster (for example 1.2-6.3 h for Roseobacter sp., Christie-Oleza et al., 2012) and should outcompete Planctomycetes. However, the phototroph-planctomycetal allelopathic interactions might involve the production of various secondary metabolites that might exhibit antimicrobial activity (defense against other, faster growing, heterotrophic bacteria) or algicidal (to destroy algae, diatoms or cyanobacteria for scavenging). The latter is supported by a positive correlation of planctomycetal abundance with chlorophyll a concentrations, pointing toward remineralization of algal biomass after blooming events through Planctomycetes (Pizzetti et al., 2011b).

Planctomycetes were found to possess secondary metabolite gene clusters employing genome mining, targeting nonribosomal peptide synthetases (NRPSs) and polyketide synthases (PKSs) encoding genes (Donadio et al., 2007). In the same year, planctomycetal type I polyketide keto-synthase domains were identified in two costal Antarctic sediments (Zhao et al., 2008). Only recently, we followed a holistic approach and combined comprehensive genome mining with physiological studies to improve our understanding of the planctomycetal potential to degrade algal polysaccharides and to produce secondary metabolites (Jeske et al., 2013). We further supported the hypothesis of allelopathic interactions between Planctomycetes and phototrophs and found, from a genomic perspective, Planctomycetes to be 'talented' producers.

In this study we employed chemical assays with planctomycetal crude extracts and biological screening methods for live visualization to prove the planctomycetal production of molecules with antibiotic activity. We further developed the entire set of tools ranging from cultivating marine and limnic Planctomycetes in chemical defined media within processcontrolled bioreactors, to the preparation of planctomycetal extracts, their chromatographic separation, fractionation and biological screening. Here, we provide the starting point for the in depth investigation of novel planctomycetal antibiotics.

\section{MATERIALS AND METHODS}

\section{General Cultivation of Microorganisms}

In this study, the novel chemically defined Maintain Medium 1 (MM1) was developed for P. limnophila DSM 3776. MM1 consists of artificial freshwater $\left(10 \mu \mathrm{M} \mathrm{NH} 4 \mathrm{Cl}, 10 \mu \mathrm{M} \mathrm{KH}_{2} \mathrm{PO}_{4}\right.$, $100 \mu \mathrm{M} \mathrm{KNO}_{3}, 200 \mu \mathrm{M} \mathrm{MgSO}_{4} 7 \mathrm{H}_{2} \mathrm{O}, 100 \mu \mathrm{M} \mathrm{CaCl}_{2} 2 \mathrm{H}_{2} \mathrm{O}$, $250 \mu \mathrm{M} \mathrm{CaCO}_{3}$, and $300 \mu \mathrm{M} \mathrm{NaHCO}_{3}$ ), that was supplemented 
with $20 \mathrm{ml} / 1$ mineral salts solution and $5 \mathrm{ml} / \mathrm{l}$ vitamin solution (double concentrated) and buffered with either $10 \mathrm{mM}$ HEPES or $100 \mathrm{mM}$ sodium phosphate buffer at $\mathrm{pH}$ 7.2. While HEPES was added before autoclaving, the sodium phosphate buffer ingredients (200 mM NaH${ }_{2} \mathrm{PO}_{4} \mathrm{H}_{2} \mathrm{O} ; 200 \mathrm{mM} \mathrm{Na}_{2} \mathrm{HPO}_{4} 7 \mathrm{H}_{2} \mathrm{O}$ ) were separately autoclaved and added afterward $(28 \mathrm{ml} / \mathrm{l}$ of mono salt solution and $72 \mathrm{ml} / \mathrm{l}$ di-salt solution). Mineral salt solution and vitamin solution were prepared according to DSMZ medium $621^{1}$. The metal salts for the mineral salt solution consisted of $250 \mathrm{mg} / \mathrm{l} \mathrm{Na-EDTA,} 1095 \mathrm{mg} / \mathrm{ZnSO}_{4} 7 \mathrm{H}_{2} \mathrm{O}, 500$ mg/l FeSO 4 $\mathrm{H}_{2} \mathrm{O}, 154 \mathrm{mg} / \mathrm{l} \mathrm{MnSO} \mathrm{H}_{2} \mathrm{O}, 39.5 \mathrm{mg} / \mathrm{l} \mathrm{CuSO}{ }_{4} 7 \mathrm{H}_{2} \mathrm{O}, 20.3 \mathrm{mg} / \mathrm{l}$ $\mathrm{CoCl}_{2} 6 \mathrm{H}_{2} \mathrm{O}, 17.7 \mathrm{mg} / \mathrm{l} \mathrm{Na} \mathrm{B}_{4} \mathrm{O}_{7} 10 \mathrm{H}_{2} \mathrm{O}$ of which $50 \mathrm{ml}$ were added per liter of mineral salt solution. To allow growth in MM1, $10 \mathrm{ml} / \mathrm{l}$ sterile filtered carbon source $(2.5 \%$ glucose solution or $5 \%$ $\mathrm{N}$-acetyl-D-glucosamine (NAG) solution) was added.

For Rhodopirellula baltica SH1 DSM 10527, the chemically defined Maintain Medium 2 (MM2) was developed in this study. MM2 is composed of $250 \mathrm{ml} / \mathrm{l} \mathrm{2x}$ artificial sea water $(46.94 \mathrm{~g} / \mathrm{l}$ $\mathrm{NaCl}, 7.84 \mathrm{~g} / \mathrm{l} \mathrm{Na} \mathrm{SO}_{4}, 21.28 \mathrm{~g} / \mathrm{l} \mathrm{MgCl} 26 \mathrm{H}_{2} \mathrm{O}, 2.86 \mathrm{~g} / \mathrm{l} \mathrm{CaCl} 22$ $\mathrm{H}_{2} \mathrm{O}, 0.384 \mathrm{~g} / \mathrm{l} \mathrm{NaHCO}_{3}, 1.384 \mathrm{~g} / \mathrm{l} \mathrm{KCL}, 0.192 \mathrm{~g} / \mathrm{l} \mathrm{KBr}, 0.052 \mathrm{~g} / \mathrm{l}$ $\mathrm{H}_{3} \mathrm{BO}_{3}, 0.08 \mathrm{~g} / \mathrm{l} \mathrm{SrCl}_{2} 6 \mathrm{H}_{2} \mathrm{O}$, and $0.006 \mathrm{~g} / \mathrm{l} \mathrm{NaF}$ ) supplemented with $5 \mathrm{ml} / \mathrm{l} 1 \mathrm{M}$ Tris/ $\mathrm{HCl} \mathrm{pH} \mathrm{7.5,20}$ and $5 \mathrm{ml} / \mathrm{l}$ vitamin solution (double concentrated, added after autoclaving) while buffered at $\mathrm{pH}$ 7.5. To allow growth in MM2, $40 \mathrm{ml} / \mathrm{l}$ sterile filtered carbon source $(2.5 \%$ glucose solution or $5 \% \mathrm{NAG})$ was added.

For strain Pan216 the novel M1H NAG ASW culture broth was developed in this study. It is composed of $250 \mathrm{ml} / 12 \mathrm{x}$ artificial sea water $\left(46.94 \mathrm{~g} / \mathrm{l} \mathrm{NaCl}, 7.84 \mathrm{~g} / \mathrm{l} \mathrm{Na} \mathrm{SO}_{4}, 21.28 \mathrm{~g} / \mathrm{l} \mathrm{MgCl}_{2}\right.$ $6 \mathrm{H}_{2} \mathrm{O}, 2.86 \mathrm{~g} / \mathrm{CaCl}_{2} 2 \mathrm{H}_{2} \mathrm{O}, 0.384 \mathrm{~g} / \mathrm{l} \mathrm{NaHCO}_{3}, 1.384 \mathrm{~g} / \mathrm{l}$ $\mathrm{KCl}, 0.192 \mathrm{~g} / \mathrm{l} \mathrm{KBr}, 0.052 \mathrm{~g} / \mathrm{l} \mathrm{H}_{3} \mathrm{BO}_{3}, 0.08 \mathrm{~g} / \mathrm{l} \mathrm{SrCl} \mathrm{H}_{2} 6 \mathrm{H}_{2} \mathrm{O}$, and $0.006 \mathrm{~g} / \mathrm{l} \mathrm{NaF}$ ), supplemented with $0.25 \mathrm{~g} / \mathrm{l}$ peptone, $0.25 \mathrm{~g} / \mathrm{l}$ yeast extract, $20 \mathrm{ml} / 1 \mathrm{mineral}$ salts solution, $20 \mathrm{ml} / \mathrm{l} 5 \%(\mathrm{w} / \mathrm{v})$ NAG solution, $10 \mathrm{ml} / \mathrm{l} 2.5 \%$ (w/v) glucose and $5 \mathrm{ml} / \mathrm{l}$ vitamin solution (double concentrated), $1 \mathrm{ml} / \mathrm{l}$ trace element solution $[1500 \mathrm{mg} / \mathrm{l}$ $\mathrm{N}\left(\mathrm{CH}_{2} \mathrm{COONa}\right)_{3} \mathrm{H}_{2} \mathrm{O}, 500 \mathrm{mg} / \mathrm{MnSO}_{4} \mathrm{H}_{2} \mathrm{O}, 100 \mathrm{mg} / \mathrm{FeSO}_{4}$ $7 \mathrm{H}_{2} \mathrm{O}, 100 \mathrm{mg} / \mathrm{l} \mathrm{Co}\left(\mathrm{NO}_{3}\right)_{2} 6 \mathrm{H}_{2} \mathrm{O}, 100 \mathrm{mg} / \mathrm{l} \mathrm{ZnCl}, 50 \mathrm{mg} / \mathrm{l}$ $\mathrm{NiCl}_{2} 6 \mathrm{H}_{2} \mathrm{O}, 50 \mathrm{mg} / \mathrm{l} \mathrm{H}_{2} \mathrm{SeO}_{3}, 10 \mathrm{mg} / \mathrm{l} \mathrm{CuSO}{ }_{4} 5 \mathrm{H}_{2} \mathrm{O}, 10 \mathrm{mg} / \mathrm{l}$ $\mathrm{AlK}\left(\mathrm{SO}_{4}\right)_{2} 12 \mathrm{H}_{2} \mathrm{O}, 10 \mathrm{mg} / \mathrm{l} \mathrm{H}_{3} \mathrm{Bo}_{3}, 10 \mathrm{mg} / \mathrm{l} \mathrm{NaMoO} 42 \mathrm{H}_{2} \mathrm{O}$, $10 \mathrm{mg} / \mathrm{l} \mathrm{Na} \mathrm{WO}_{4} 2 \mathrm{H}_{2} \mathrm{O}$ ] and buffered with $10 \mathrm{mM}$ HEPES at $\mathrm{pH}$ 8.0 .

All strains were cultivated at $28^{\circ} \mathrm{C}$ in their respective culture broth with slight agitation $(80 \mathrm{rpm})$.

Indicator strains were cultured according to DSMZ cultivation recommendations ${ }^{2}$.

\section{Phylogeny of Strain Pan216}

Pan216 was identified by $16 \mathrm{~S}$ rRNA gene sequencing after amplification with the modified universal primers $8 \mathrm{f}\left(5^{\prime}\right.$-AGA GTT TGA TCM TGG CTC AG-3') and 1492r (5'-GGY TAC CTT GTT ACG ACT T-3'; Lane, 1991). PCR reactions were performed directly on single colonies or liquid cultures using the Taq DNA Polymerase (Qiagen) with one reaction of $25 \mu \mathrm{l}$ containing $11 \mu \mathrm{l}$ PCR-grade $\mathrm{H}_{2} \mathrm{O}, 2.5 \mu \mathrm{l}$ 10x CoralLoad buffer, $2.5 \mu \mathrm{l}$ Q-Solution,

\footnotetext{
${ }^{1}$ https://www.dsmz.de/

${ }^{2}$ https://www.dsmz.de/catalogues/dzif-sammlung-der-dsmz/indikatorstaemmefuer-wirkstoffforschung.html.
}

$0.5 \mu \mathrm{l}$ dNTPs (10 $\mathrm{mM}$ each), $1 \mu \mathrm{l}$ sterile bovine serum albumin solution $(20 \mathrm{mg} / \mathrm{ml}), 0.5 \mu \mathrm{l} \mathrm{MgCl}_{2}$ solution $(25 \mathrm{mM}), 0.125 \mu \mathrm{l}$ Taq-Polymerase $(1 \mathrm{U} / \mu \mathrm{l})$ and $1 \mu \mathrm{l}$ of each primer $(10 \mathrm{pmol})$. The employed protocol consisted of two steps, the first step with an initial denaturation at $94^{\circ} \mathrm{C}, 5 \mathrm{~min}, 10$ cycles of denaturation at $94^{\circ} \mathrm{C}, 30 \mathrm{~s}$, annealing at $59^{\circ} \mathrm{C}, 30 \mathrm{~s}$, elongation at $72^{\circ} \mathrm{C}, 1 \mathrm{~min}$, followed by the second step with 20 cycles denaturation at $94^{\circ} \mathrm{C}$, $30 \mathrm{~s}$, annealing at $54^{\circ} \mathrm{C}, 30 \mathrm{~s}$, elongation at $72^{\circ} \mathrm{C}, 1 \mathrm{~min}$, and a final elongation step at $72^{\circ} \mathrm{C}, 7 \mathrm{~min}$. All PCRs were carried out in an Applied Biosystems ${ }^{\circledR}$ Veriti $^{\circledR}$ thermal cycler (Thermo Fisher Scientific) and PCR products were stored at $4^{\circ} \mathrm{C}$ until Sanger-sequencing.

Near full length $16 \mathrm{~S}$ sequences were generated by assembly of the resulting sequences with the ContigExpress application of the Vector NTI ${ }^{\circledR}$ Advance 10 software (Thermo Fisher Scientific).

Alignments of near full length 16S rRNA sequences were performed using the SINA web aligner (Pruesse et al., 2012), corrected manually and used for phylogenetic tree reconstruction (Supplementary Figure S1). Tree reconstruction was performed with the ARB software package (Ludwig et al., 2004) using the Maximum likelihood RAxML module and rate distribution model GTR GAMMA running the rapid bootstrap analysis algorithm, the Neighbor Joining tool with Felsenstein correction for DNA and Maximum Parsimony method employing the Phylip DNAPARS module. Bootstrap values for all three methods were computed with 1,000 resamplings including the Escherichia coli 16S rRNA gene positions 101-1438. The analysis involved a total of 37 nucleotide sequences of described type strains and outgroup strains (gray box; compare Supplementary Table S2).

\section{Growth Measurement of Planctomycetes}

To measure growth of $P$. limnophila in the different cultivation media (Figure 1A), $250 \mathrm{ml}$ baffled flasks with $70 \mathrm{ml}$ respective growth medium were inoculated with $10 \mathrm{ml}$ pre-culture, which were washed twice with MM1 prior inoculation. Likewise, $R$. baltica and Pan216 were incubated with different carbon sources (Figures 1B,C) and inoculated with a pre-culture washed twice with MM2. Afterward, the respective carbon source was supplemented ( $4 \mathrm{ml}$ of $2.5 \%$ glucose, $4 \mathrm{ml}$ of $2.5 \%$ dextran, or $2 \mathrm{ml}$ of $5 \% \mathrm{NAG}$ ). As control P. limnophila was grown in M1 and $R$. baltica in M2 medium (Jeske et al., 2013) while Pan216 was grown in M1H NAG ASW medium. Individual growth conditions were analyzed in three biological replicates. The optical density of the culture was measured every 8 and $16 \mathrm{~h}$ at $600 \mathrm{~nm}$ with a spectrophotometer.

\section{Cultivation of Planctomycetes in a Bioreactor}

The respective growth medium was autoclaved in a 3681 chamber autoclave (BeliMed) within the 101 culture vessel of the bioreactor (UniVessel, Sartorius). After sterile supplementation of the respective vitamins and carbon source the reactor was incubated for 2 days to exclude contaminations. For sterile inoculation, a planctomycetal pre-culture (0.1 volume) was transferred via a culture bottle into the $10 \mathrm{l}$ culture vessel of the BIOSTAT $^{\circledR}$ B system. 


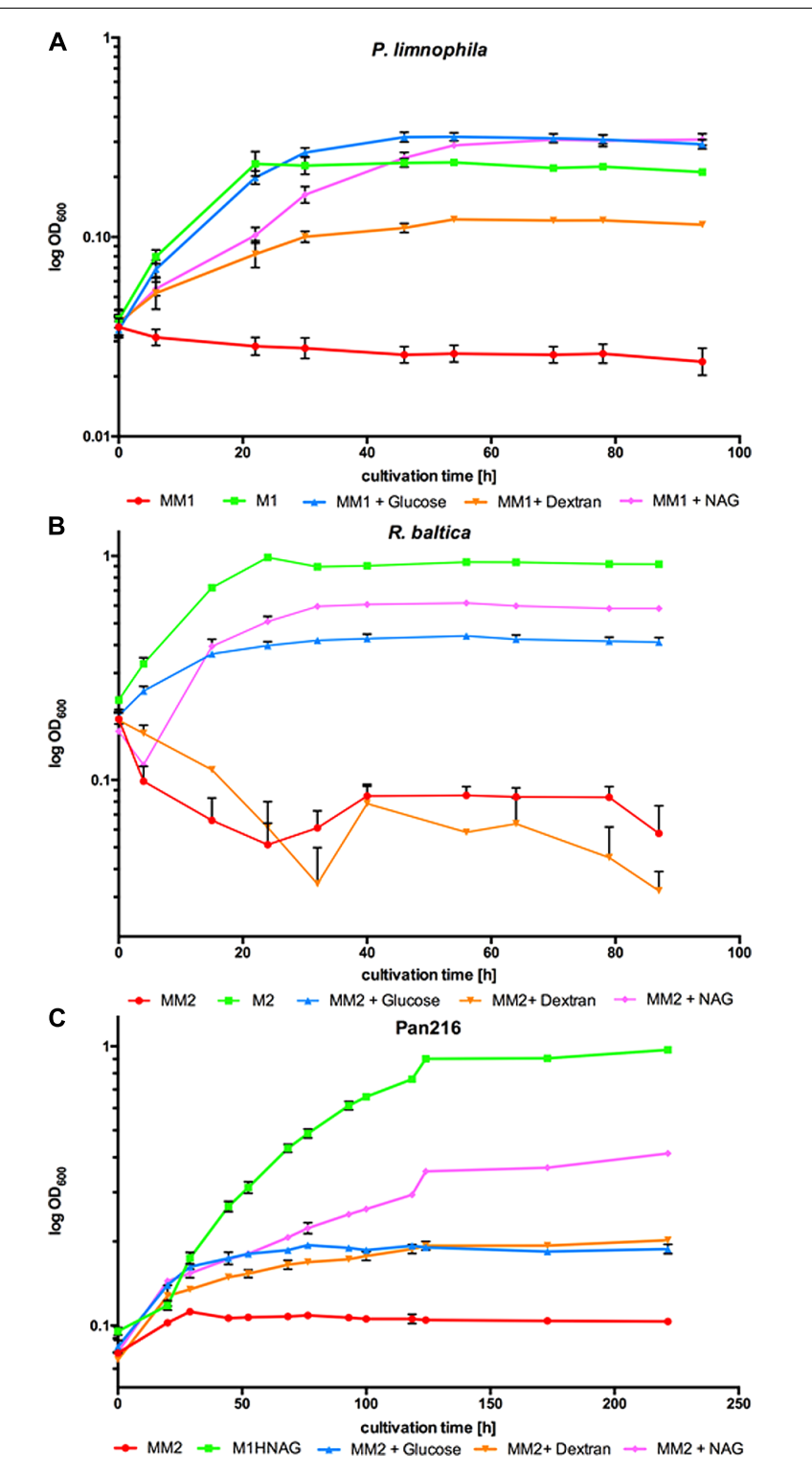

FIGURE 1 | Growth of Planctopirus limnophila, Rhodopirellula baltica and strain Pan216 under different cultivation conditions. Logarithmic $\mathrm{OD}_{600}$ values as measure of growth over $96 \mathrm{~h}$ for (A) P. limnophila, (B) R. baltica and $255 \mathrm{~h}$ for (C) strain Pan216 under different cultivation conditions: M1 and M2: complex culture media containing yeast extract, peptone and glucose (green curves). Maintain medium 1 or Maintain medium 2 (MM1 and MM2) are chemically defined but lack a carbon source and thus, unsupplemented, do not allow for bacterial growth of Planctomycetes (red curves). MM1 and MM2 were supplemented with glucose (blue curves), dextran (orange curves) or $\mathrm{N}$ - acetyl-D-glucosamine (NAG; pink curves) to allow growth of $P$. limnophila, $R$. baltica and strain Pan216. Each time point represents the mean of triplicate measurements.

Planctopirus limnophila was cultured at $28^{\circ} \mathrm{C}$ in $\mathrm{MM} 1$ supplemented with glucose with a constant $\mathrm{pH}$ of 7.2 at $100 \mathrm{rpm}$ agitation and a constant air supply ( $0.5 \mathrm{bar}, 0.85 \mathrm{l} / \mathrm{min})$. Samples for glucose consumption, $\mathrm{OD}_{600}$ and biomass determination were taken every $24 \mathrm{~h}$ (Figure 3A).
In contrast, $R$. baltica was cultured in MM2 supplemented with glucose at $\mathrm{pH} 7.5$ with otherwise identical parameters (Figure 3B).

For fed-batch cultivation the P. limnophila culture was spiked after 7 days with $25 \mathrm{ml} \mathrm{NAG}$ and $10 \mathrm{ml}$ vitamin solution and cultured for 10 more days (Supplementary Figure S3).

\section{Extraction of Secondary Metabolites from Planctomycetes}

For crude extract preparation, $600 \mathrm{ml}$ of a $P$. limnophila culture were incubated with $2 \%(\mathrm{v} / \mathrm{v})$ of purified adsorbent resin XAD$16 \mathrm{~N}$ (Rohm and Haas) at $28^{\circ} \mathrm{C}$ with $80 \mathrm{rpm}$ agitation in a baffled flask for 3 days. The XAD- $16 \mathrm{~N}$ was collected by filtration through an analysis sieve and transferred into an extraction flask. $200 \mathrm{ml}$ acetone were added and incubated in darkness for $1 \mathrm{~h}$ at room temperature. To remove the XAD resin the eluate was filtered (Macherey and Nagel 615 1/4 , pore size 4$12 \mu \mathrm{m}$ ) after incubation. In parallel, cells were harvested by centrifugation and suspended in $200 \mathrm{ml}$ acetone for $1 \mathrm{~h}$ in darkness at room temperature, followed by filtration. Employing a rotary evaporator (Hei VAP-Precision Heidolph) the acetone was removed to yield a solid residue $\left(36^{\circ} \mathrm{C}\right.$; at $\left.130 \mathrm{rpm} ; 1 \mathrm{mbar}\right)$. The obtained residues were dissolved in $1 \mathrm{ml}$ methanol (pA) and stored at $-20^{\circ} \mathrm{C}$. Extracts for R. baltica and Pan 216 were prepared in the same manner. Cultures of Pan 216 and XAD were harvested after 5 days of incubation due to their slower growth.

\section{Measurement of Biomass Production and Glucose Consumption}

To determine the dry weight of the planctomycetal cells at the given time points, $25 \mathrm{ml}$ of the respective culture were filtered through two superimposed filters with a pore size of $2.5 \mu \mathrm{m}$ each (Whatman Grade 5 Qualitative Filter Paper) employing a vacuum pump operating at 800 mbar. The filters were subsequently dried for $60 \mathrm{~min}$ at $80^{\circ} \mathrm{C}$. Comparison of filter weight before and after filtration gave the bacterial dry mass. The glucose concentration was determined with a test strip (MQuantTM) according to the manufacturer's description.

\section{Minimum Inhibitory Concentration Assay}

To examine the minimum inhibitory concentrations (MICs) of planctomycetal crude extracts, 26-56 $\mu \mathrm{l}$ of indicator bacteria (for detailed information see Supplementary Table S1) were added to $20 \mathrm{ml}$ of their respective culture medium and mixed well. The indicator strain stocks contained each $1 \mathrm{ml}$ bacteria suspension with an $\mathrm{OD}_{600}$ of 3.54 for E. coli DSM 1116, 4.05 for E. coli TolC, 7.7 Micrococcus luteus DSM 1790, 3.69 for Bacillus subtilis DSM 10 and 3.86 for Staphylococcus aureus DSM 346. Subsequent aliquots were stored at $-80^{\circ} \mathrm{C}$ until usage. $150 \mu \mathrm{l}$ of the diluted culture was dispensed into each well of a 96well microtiter plate (initial $\mathrm{OD}_{600}$ for the indicator bacteria was 0.01 ). An additional $130 \mu \mathrm{l}$ of diluted indicator culture was added to the first row. $20 \mu \mathrm{l}$ of the planctomycetal crude extracts were added to the first row. A serial dilution of the extract (1:1) was made by transferring $150 \mu \mathrm{l}$ from one well to the next, this was done from row $\mathrm{A}$ to $\mathrm{H}$. For negative and positive 


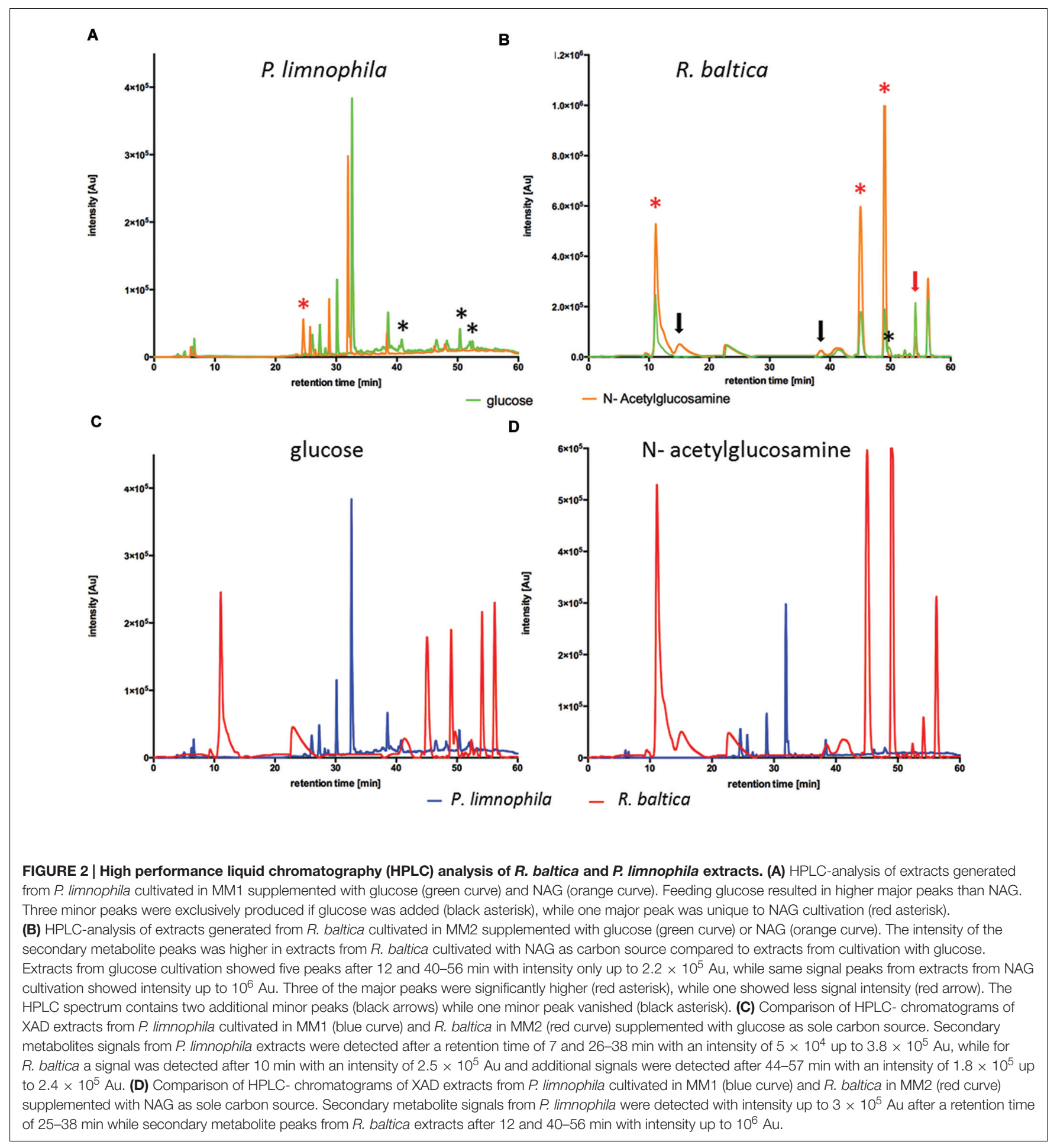

controls either $20 \mu \mathrm{l}$ methanol or $20 \mu \mathrm{l}$ of the respective culture medium were added instead of planctomycetal crude extracts. Subsequently, the microtiter plates were incubated for $24 \mathrm{~h}$ under constant agitation $(150 \mathrm{rpm})$ at 30 or $37^{\circ} \mathrm{C}$. After incubation, the growth of the indicator strains was reviewed visually. No turbidity of the media in a well showed an inhibition of the indicator strain.

\section{Agar Plate Diffusion Assay}

To determine antibiotic activity, filter disks (5 $\mathrm{mm}$ diameter, pore size 4-7 $\mu \mathrm{m}$; Whatman No 597) were coated with $90 \mu \mathrm{l}$ of planctomycetal crude extracts, while methanol (pA) coated disks served as negative control. The treated disks were placed on soft-agar plates inoculated with B. subtilis cells and incubated over night at $28^{\circ} \mathrm{C}$. Soft-agar plates consisted of a $10 \mathrm{ml} 1.5 \%$ 


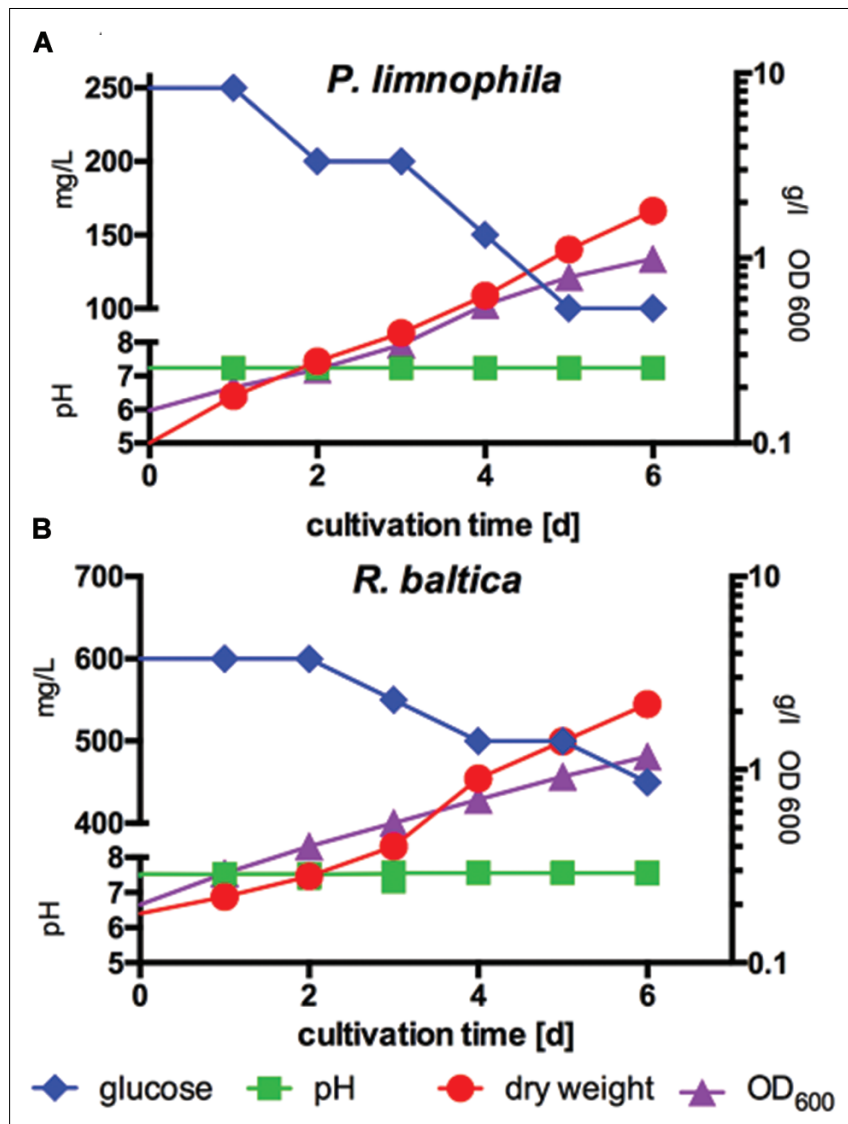

FIGURE 3 | Measurement of biomass production compared to optical density and glucose consumption of $P$. limnophila and $R$. baltica at constant pH. (A) Biomass production of P. limnophila compared to optical density at $600 \mathrm{~nm}\left(\mathrm{OD}_{600}\right)$ and glucose consumption at constant $\mathrm{pH}$ over 6 days in MM1 supplemented with glucose in a 10 I fermenter. Glucose concentration decreased from 250 to $100 \mathrm{mg} / \mathrm{l}$ (blue curve), while the $\mathrm{OD}_{600}$ increased from 0.15 up to 0.99 (purple curve) and correlating with the $\mathrm{OD}_{600}$ also the dry weight increased from $0.1 \mathrm{~g} / \mathrm{l}$ up to $1.8 \mathrm{~g} / \mathrm{l}$ (red curve) during cultivation. The $\mathrm{pH}$ was 7.2 (green curve). (B) Biomass production of $R$. baltica compared to, $\mathrm{OD}_{600}$-value and glucose consumption at constant $\mathrm{pH}$ over 6 days in MM2 supplemented with glucose in a 10 I fermenter. Glucose concentration decreased from 600 to $450 \mathrm{mg} / \mathrm{l}$ (blue curve), while the $\mathrm{OD}_{600}$ increased from 0.2 to 1.170 (purple curve) and correlating with the $\mathrm{OD}_{600}$ also the dry weight increased from $0.18 \mathrm{~g} / \mathrm{l}$ and to $2.18 \mathrm{~g} / \mathrm{l}$ (red curve) during cultivation. The $\mathrm{pH}$ was stabilized at 7.5 (green curve).

LB agar layer covered with a second layer of $10 \mathrm{ml} 0.7 \% \mathrm{LB}$ agar inoculated with $100 \mu \mathrm{l}$ of a B. subtilis DSM10 overnight culture.

\section{Dual Culture Assay}

Dual culture assays were performed on M2 1.5\% agar plates with $R$. baltica producer and E. coli DSM 1116 as indicator strain. Given the different doubling times of both species, $R$. baltica was inoculated first and incubated for 2 days at $28^{\circ} \mathrm{C}$. Afterward, $E$. coli was inoculated on the same plate and the agar dishes were incubated for three more days at $28^{\circ} \mathrm{C}$. To investigate if growth-altering effects appear in a distance-dependent manner, respective bacteria were plated at different defined distances from each other $(2,10$, and $15 \mathrm{~mm}$ respectively).

\section{HPLC-Analysis of Planctomycetal Extracts}

High performance liquid chromatography (HPLC) analysis was performed with a Prominence HPLC (Shimadzu) equipped with a Macherey and Nagel, CC 250/4.6 NUCLEODUR 1005 C18 column (pore size $100 \AA ̊$, particle size $5 \mu \mathrm{m}$ ) coupled to a SPD-M20A photo diode array (PDA) detector (Shimadzu). The PDA detector recorded all emitted wavelengths, while the wavelength with the highest signal intensities $(254 \mathrm{~nm})$ was used for further discrimination of the extracts. $15 \mu$ l of the investigated extracts were injected and eluted with a modified methanolwater gradient [solvent $\mathrm{A}: \mathrm{H}_{2} \mathrm{O}$; solvent $\mathrm{B}$ : methanol, gradient: $5 \% \mathrm{~B}$ for $10 \mathrm{~min}$ increasing to $100 \% \mathrm{~B}$ in $15 \mathrm{~min}$, maintaining $100 \% \mathrm{~B}$ for $30 \mathrm{~min}$, flow rate (FR) $0.6 \mathrm{ml} / \mathrm{min}$ ]. Prior to the analysis of the extracts, the column was equilibrated with pure methanol. Results were analyzed using the LCsolution Shimadzu Software.

\section{HPLC Fractionation}

An Agilent 1260 Series HPLC-UV system equipped with a Waters, XBridge BEH C18, $2.1 \mathrm{~mm} \times 100 \mathrm{~mm}$ column (pore size $135 \AA$, particle size $3.5 \mu \mathrm{m}$ ) was used for the chromatographic fractionation of crude extracts. The same HPLC gradient was used as for the high-resolution electrospray ionization mass spectrometry (HRESIMS) instrument (described below). The flow through was collected in $30 \mathrm{~s}$ intervals into a 96-well microtiter plate. Afterward, the plates were dried by a constant nitrogen-flush for $40 \mathrm{~min}$, inoculated with $150 \mu \mathrm{l}$ indicator bacteria per well and incubated as described above. After $24 \mathrm{~h}$ the plates were evaluated and documented employing a custom-made mirror stand and a CANON EOS 10D digital camera.

\section{Mass Spectra}

Electrospray ionization mass spectrometry (ESIMS) spectra in positive and negative mode were obtained with an Agilent 1260 Infinity Series HPLC-UV system (column $2.1 \mathrm{~mm} \times 50 \mathrm{~mm}$, $1.7 \mu \mathrm{m}, \mathrm{C} 18$ Acquity UPLC BEH (Waters), solvent A: $\mathrm{H}_{2} \mathrm{O}+$ $0.1 \%$ formic acid; solvent $\mathrm{B}$ : $\mathrm{ACN}+0.1 \%$ formic acid, gradient: $5 \% \mathrm{~B}$ for $0.5 \mathrm{~min}$ increasing to $100 \% \mathrm{~B}$ in $19.5 \mathrm{~min}$, maintaining $100 \%$ B for $5 \mathrm{~min}$, FR $0.6 \mathrm{ml} / \mathrm{min}$, UV detection 200-600 nm) equipped with a diode array detector and an ESIiontrap MS detector (Amazon, Bruker).

High-resolution electrospray ionization mass spectrometry spectra were obtained with an Agilent 1200 series HPLC-UV system [solvent A: $\mathrm{H}_{2} \mathrm{O} / \mathrm{ACN}(95 / 5)+5 \mathrm{mM} / \mathrm{l}$ of $\mathrm{NH}_{4} \mathrm{Ac}$ $+40 \mu \mathrm{l} / \mathrm{l}$ of acetic acid; solvent $\mathrm{B}: \mathrm{H}_{2} \mathrm{O} / \mathrm{ACN}(5 / 95)+$ $5 \mathrm{mM} / \mathrm{l}$ of $\mathrm{NH}_{4} \mathrm{Ac}+40 \mu \mathrm{l} / \mathrm{l}$ of acetic acid, gradient: $10 \%$ $\mathrm{B}$ increasing to $100 \% \mathrm{~B}$ in $30 \mathrm{~min}$, maintained $100 \% \mathrm{~B}$ for $10 \mathrm{~min}$; $F R=0.3 \mathrm{ml} / \mathrm{min}$; UV detection 200-600 $\mathrm{nm}$ ] combined with an ESI-TOF-MS (Maxis, Bruker; scan range 100$2500 \mathrm{~m} / \mathrm{z}$, rate $2 \mathrm{~Hz}$, capillary voltage $4500 \mathrm{~V}$, dry temperature $\left.200^{\circ} \mathrm{C}\right)$. 


\section{RESULTS}

\section{Chemically Defined Growth Conditions for Marine and Limnic Planctomycetes}

We selected the marine species $R$. baltica SH1 DSM 10527 and the limnic organism P. limnophila DSM 3776 as model Planctomycetes together with the phylogenetically distant and recently isolated strain Pan216 (Supplementary Figure S1) for subsequent experiments. For both established model species, optimized growth conditions in complex media, containing rather high amounts of yeast extract and peptone, have been previously described (Jogler et al., 2011; Jeske et al., 2013). The optimal growth conditions in rich media for strain Pan216 were determined in this study (see Materials and Methods).

To enable ecomimetic experiments that mimic certain natural conditions in the laboratory, and to optimize HPLC detection and fractionation, we developed a chemically defined and carbon source free maintain medium for limnic- (MM1) and marine conditions (MM2). P. limnophila, R. baltica, and Pan216 cells survived under such conditions, but were not able to divide and grow without supplementation of any maintain medium with a carbon source (Figure 1, red curves). After a starvation period (5-9 days) in the respective Maintain Media, all three strains were able to fully recover when specific carbon and nitrogen sources were added. Remarkably, $P$. limnophila grew even more efficiently in MM1 + glucose (same growth rate but higher biomass attained; Figure 1A, blue curve) or MM1 + NAG (lower growth rate but higher biomass attained; Figure 1A, pink curve), than in the originally described isolation medium (Figure 1A, green curve). $R$. baltica grew less efficiently with $\mathrm{MM} 2+$ glucose (Figure 1B, blue curve) or MM2 + NAG (Figure 1B, pink curve) and did not reach the same $\mathrm{OD}_{600}$ compared to the medium culture broth M2 (Figure 1B, green curve). Pan216 grew best if fed with M1H NAG ASW medium developed in this study (Figure 1C, green curve). The chemically defined MM media were also supplemented with other carbon sources such as the complex polysaccharide dextran (Figure 1, orange curves) that provided growth for P. limnophila and Pan216 but not for $R$. baltica. In the case of $R$. baltica, the supplementation of NAG (Figure 1B, pink curve) led to initial biofilm formation resulting in an early decrease of the cultures optical density. This effect was even stronger after adding dextran (Figure 1B, orange curve) and explains why the optical density was lower than in the control culture (Figure 1B, red curve) without any carbon source added. Thus certain carbon sources might trigger a lifestyle switch from planktonic growth to biofilm formation.

The adsorber resin XAD binds unspecifically to both secreted secondary metabolites and components of the complex growth media M1 and M2, resulting in visible media component signals in HPLC measurements even when no-bacteria medium control samples were measured (Supplementary Figures S2A,C). However, extraction of our newly developed MM1 and MM2 media with XAD showed no media component signals in HPLC analysis (Supplementary Figures S2B,C), making them the preferred choice to investigate the influence of trigger substances on secondary metabolite production in Planctomycetes.

\section{Ecomimetic Cultivation of Planctomycetes}

The chemically defined Maintain Media (MM) were developed to enable ecomimetic experiments which attempt to recreate environmental situations under defined conditions in the laboratory. The rational was that certain environmental cues, such as a particular carbon source, would stimulate secondary metabolite production in Planctomycetes, and consequently alter the peak profile in subsequent HPLC analysis. For a proof of principle, we simulated the planctomycetal interaction with cyanobacteria by adding a key component of bacterial cell walls -NAG - to our MM. Since cyanobacteria occur in both, marine- and limnic habitats, we performed the evaluation of our MMs with R. baltica (marine) and P. limnophila (limnic) in MM2 and MM1 respectively. After cultivation with XAD for 3 days at $28^{\circ} \mathrm{C}$, XAD extracts were analyzed via HPLC. For $P$. limnophila, three minor peaks were exclusively detected when cells were cultivated with glucose as sole carbon source (Figure 2A, black asterisk), while one peak was unique to cultivation with NAG as sole carbon source (Figure 2A, red asterisk). When cultivated with glucose, $R$. baltica produced secondary metabolites that led to five major and five minor peaks in the HPLC chromatogram (Figure 2B, green curve). In contrast, when fed with NAG, the subsequent HPLC chromatogram contains two additional minor peaks (Figure 2B, black arrows) while one minor peak vanished (Figure 2B, black asterisk). Three of the major peaks were significantly higher (Figure 2B, red asterisk), while one showed less signal intensity (Figure 2B, red arrow). The overall signal intensity of $P$. limnophila extracts showed less variation between the cultivation conditions than $R$. baltica did. However, comparison of extracts from P. limnophila (Figures 2C,D, blue) and R. baltica (Figures 2C,D, red) showed that both organisms display entirely different HPLC peak patterns.

Thus our Maintain Media allow ecomimetic experiments that lead to the production of different metabolites in response to different carbon sources.

\section{Screening of Planctomycetal Extracts for Antimicrobial Activity}

One aim of this study was to develop cultivation techniques that could stimulate the production of bioactive molecules with antimicrobial activity as demonstrated in the previous section. However, extracts obtained in such ecomimetic experiments require a screening procedure to determine potential antimicrobial activity. Thus, for the first time we demonstrate different screening methods for planctomycetal extracts and strains and evaluated their usefulness.

The semi-quantitative agar plate diffusion assay was used to determine the inhibitory effect of $R$. baltica cell- and XAD resin extracts obtained from $R$. baltica cultures against B. subtilis. While the negative control and the cell extract disks showed no influence on bacterial growth, the planctomycetal XAD extract displayed a zone of $B$. subtilis growth inhibition, pointing toward an antibiotic molecule produced by $R$. baltica (Figure 4A). 
A

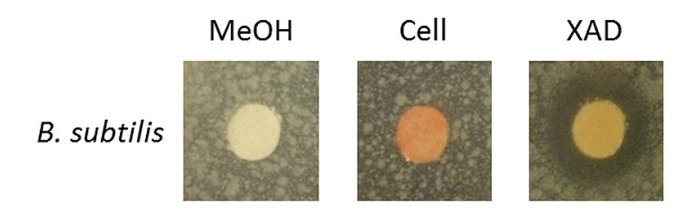

C
E. coli TolC

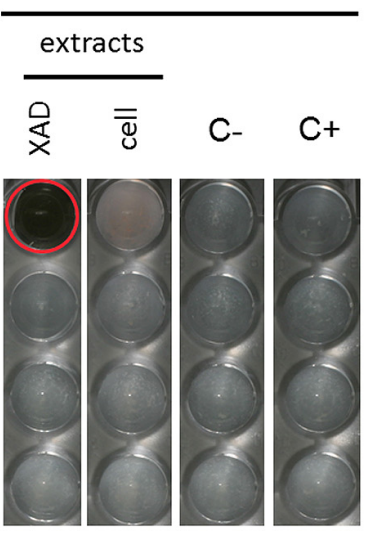

S. aureus

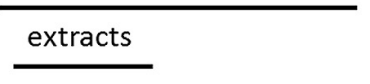

B

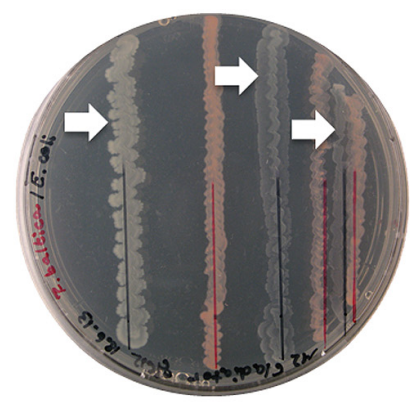

M. luteus

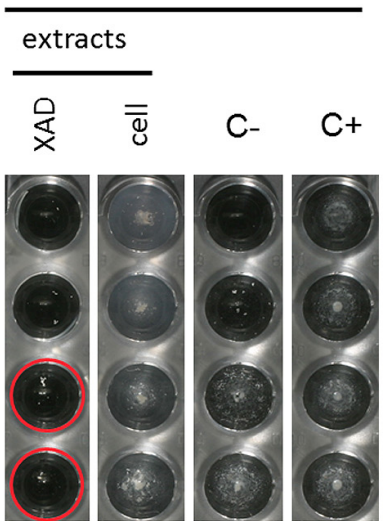

FIGURE 4 | Activity assays of $\boldsymbol{R}$. baltica methanol extracts. (A) Agar plate diffusion assay of $R$. baltica methanol cell extracts against Bacillus subtilis. Disks are coated with $90 \mu \mathrm{l}$ methanol $(\mathrm{MeOH}), R$. baltica cell or XAD extract respectively and incubated over night on soft-agar plates inoculated with $B$. subtilis. The clear areas around the disks treated with XAD extract show a distinct zone of $B$. subtilis growth inhibition, while methanol or cell extract show no effect. (B) Dual culture assay of $R$. baltica and E. coli. E. coli grew best with the maximal chosen distance of $15 \mathrm{~mm}$ to $R$. baltica. E. coli cells grew weaker when the distance was reduced to $10 \mathrm{~mm}$ and weakest at $2 \mathrm{~mm}$ (white arrows). (C) Dilution minimum inhibitory concentration (MIC) assay with R. baltica cell and XAD extracts. Growth inhibitory effect of cell and XAD methanol extracts on: treated E. coli TolC deletion mutant, S. aureus DSM 346 and M. Iuteus DSM 1790 cells. XAD: serial dilution column with XAD extract; Cell: serial dilution column with cell extract; $\mathrm{C}-$ : serial dilution column with methanol as negative control; $\mathrm{C}+$ : respectively untreated cells as positive control. Red circles highlight inhibited cells. If the same methanol concentration also inhibited the growth, the effect of the extracts was not taken into account (see $\mathbf{C}$ first two wells of XAD extract). The last well in which no bacteria grow contains the antibiotic at its minimal inhibitory concentration.

The dual culture assay revealed that reducing the distance between $R$. baltica and E. coli K12 increased the growth inhibition effect (Figure 4B). E. coli grew to highest density with the maximum chosen distance of $15 \mathrm{~mm}$. When the distance to $R$. baltica was reduced to $10 \mathrm{~mm}$, the E. coli grew less well. Ultimately, only minor growth of E. coli was observed when the distance was reduced to $2 \mathrm{~mm}$ distance.

The MIC assay was performed for $R$. baltica extracts (Figure 4C). Several dilution series were prepared against E. coli TolC, S. aureus and M. luteus. Only the highest concentration of $R$. baltica XAD extract in the first well showed an effect against the E. coli TolC strain (Figure 4C: XAD). However, a strong inhibitory effect against $S$. aureus was observed with the $R$. baltica XAD extract (Figure 4C: XAD). The first three wells of the dilution series showed a distinct inhibition of growth. The lowest concentration in which the bacterial growth was inhibited therefore contained the antibiotic at MIC. In contrast, $S$. aureus treated with the cell extract grew normally and showed no signs of growth inhibition (Figure 4C: cell).

Likewise, only the XAD extract had a strong inhibitory effect against $M$. luteus in the first four wells (Figure 4C: XAD), whereas the cell extract had no effect on M. luteus (Figure 4C: cell). However, since no bacterial growth could be detected in the first two wells of the dilution series for the negative control, the effect of the first two wells in the XAD column might be caused by methanol rather than by a potential antibiotic within the crude extract. However, bacteria were not inhibited in the third well of the negative control, so extracts with activity at this dilution could still contain an active compound.

Thus, all three evaluated screening methods, agar plate diffusion, dual culture, and MIC assay were useful to analyze planctomycetal antimicrobial activity. For the first time we demonstrated antibacterial activity of $R$. baltica against both, Gram-negative and Gram-positive bacteria.

\section{Correlation of Antimicrobial Activity with Distinct HPLC Peaks}

After development of ecomimetic cultivation, biological screening methods, and protocols to facilitate the analysis of planctomycetal antibiotic production, next the HPLC signals need to be correlated with biological activity to facilitate structure elucidation of the antibiotic molecules. Thus, we deve- 
loped a procedure that allows correlation of HPLC peaks with antimicrobial activity of planctomycetal extracts. Again, a limnic (P. limnophila) and a marine species (strain Pan216) were chosen for the proof of principle study. After cultivation and extraction of cultures with adsorbent resin, the MIC assay screening against indicator strains (Supplementary Table S1) was performed. Once the analyzed extract showed an activity against one of the indicator strains (Figures 4C and 5), a semi preparative HPLC run was performed (Figure 5). Our integrated approach consists of utilizing HPLC instruments coupled with both HRESIMS as well as a fractionation collector for 96-well microtiter plates, which are used in a subsequent bioassay against the prior determined strains. Both HPLC systems were equipped equally, so that chromatograms and retention times can directly be compared. Thereby it is possible to assign the activity observed for the crude extract to individual peaks, and simultaneously to determine their molecular formula (Figure 5; Table 1). Furthermore, tandem mass spectrometry (MS/MS) and UV/Vis spectra can sometime provide early information about the chemical structure of the desired substance. Although, the HPLC gradient and solvents can be varied, the use of a water/acetonitrile (ACN) system provided best chromatographic separation and we suggest this as standard procedure for the analysis of planctomycetal extracts. Since the use of formic acid did not lead to the reproducible detection of bioactive wells, we concluded that some of the bioactive compounds might be degraded under acidic conditions and consequently we used an acetate buffered solvent system instead.

Two replicate cultivation and extraction experiments were performed for both P. limnophila and strain Pan216.

Fractionation of $P$. limnophila replicate $\mathrm{R} 1$ resulted in inhibition of various wells. The obtained results were not reproducible and no activity could be assigned to peaks in the UV chromatogram.
In contrast, repeated fractionation of $15 \mu \mathrm{l}$ extract each for P. limnophila replicate R2 led to reproducible inhibition of $B$. subtilis growth in well 'B6', which had been collected from 23 to $23.5 \mathrm{~min}$ (Table $\mathbf{1}$ ). The chromatogram showed a major peak at this retention time (Figure 5A). The same peak was observed at a retention time of $22.4 \mathrm{~min}$ in the HRESIMS system. Its molecular formula $\mathrm{C}_{26} \mathrm{H}_{51} \mathrm{NO}_{6}$ was deduced from its $[\mathrm{M}+\mathrm{H}]^{+}$peak at $m / z 474.3880$ as well as its $[\mathrm{M}+\mathrm{Na}]^{+}$, $[2 \mathrm{M}+\mathrm{H}]^{+}$, and $[2 \mathrm{M}+\mathrm{Na}]^{+}$peaks at $\mathrm{m} / z$ 496.3608, 947.7514, and 969.7325, respectively (Table 1). The assignment of the molecular ion cluster was further confirmed by the observation of the $\left[\mathrm{M}+\mathrm{CO}_{2} \mathrm{H}\right]^{-}$peak at $\mathrm{m} / z 518.3$ in the ESIMS spectrum measured in negative mode. A search with the molecular formula $\mathrm{C}_{26} \mathrm{H}_{51} \mathrm{NO}_{6}$ in the Dictionary of Natural Products (DNPs) on DVD resulted in no known metabolites (Table 1).

In the case of strain Pan216, both replicates resulted in different inhibition patterns as well. For replicate R1 inhibition of wells B7, C7, and G7 was observed that correspond to three major peaks of the slightly lipophilic region of the chromatogram (Figure 5B). These three peaks were detected in HRESIMS spectrum at 25.1, 25.8, and $27.6 \mathrm{~min}$ and molecular formulae of $\mathrm{C}_{18} \mathrm{H}_{30} \mathrm{O}_{2}, \mathrm{C}_{22} \mathrm{H}_{32} \mathrm{O}_{2}$, and $\mathrm{C}_{22} \mathrm{H}_{34} \mathrm{O}_{2}$ were assigned from their $[\mathrm{M}+\mathrm{H}]^{+}$and $[\mathrm{M}+\mathrm{Na}]^{+}$peak pairs (Table 1). These assignments were further confirmed by $[\mathrm{M}+\mathrm{H}]^{+}[\mathrm{M}-\mathrm{H}]^{-}$pairs in positive/negative mode ESIMS spectra. The search for these molecular formulae in the DNP resulted in 122, 38, and 61 hits (Table 1).

Neither of those peaks were observed in the chromatogram of Pan216 replicate R2 nor was activity observed in wells B7G7. Instead, well C6 (23.5-24 min) was constantly inhibited. The corresponding peak shows characteristic UV absorption maxima at 244 and $294 \mathrm{~nm}$, which might suggest an aromatic residue. The $[\mathrm{M}+\mathrm{H}]^{+}$peak in the HRESIMS spectrum at $m / z 294.0532$ could indicate the molecular formula as $\mathrm{C}_{12} \mathrm{H}_{11} \mathrm{~N}_{3} \mathrm{O}_{4} \mathrm{~S}$, which would explain the observed +2 satellite

TABLE 1 | Antibacterial metabolites found in P. limnophila and Pan216.

\begin{tabular}{|c|c|c|c|c|c|c|c|}
\hline Organism & Rt [min] & $m / z^{a}$ & $\begin{array}{l}\text { Molecular } \\
\text { formula }\end{array}$ & Hits in DNP & DBE & MS/MS & Possible fragments \\
\hline P. limnophila R2 & 22.4 & $\begin{array}{l}\mathbf{4 7 4 . 3 8 8 0} \\
947.7514 \\
969.7333\end{array}$ & $\begin{array}{l}\mathrm{C}_{26} \mathrm{H}_{57} \mathrm{NO}_{6} \\
\mathrm{C}_{52} \mathrm{H}_{103} \mathrm{~N}_{2} \mathrm{O}_{12} \\
\mathrm{C}_{52} \mathrm{H}_{102} \mathrm{~N}_{2} \mathrm{O}_{12} \mathrm{Na}\end{array}$ & 0 & 2 & $\begin{array}{l}456.3685 \\
317.2845 \\
236.1495 \\
217.1954\end{array}$ & $\begin{array}{l}\mathrm{C}_{26} \mathrm{H}_{50} \mathrm{NO}_{5} \\
\mathrm{C}_{22} \mathrm{H}_{37} \mathrm{O} \\
\mathrm{C}_{10} \mathrm{H}_{22} \mathrm{NO}_{5} \\
\mathrm{C}_{16} \mathrm{H}_{25}\end{array}$ \\
\hline Pan216 R1 & 27.6 & $\begin{array}{l}331.2642 \\
353.2461\end{array}$ & $\begin{array}{l}\mathrm{C}_{22} \mathrm{H}_{35} \mathrm{O}_{2} \\
\mathrm{C}_{22} \mathrm{H}_{34} \mathrm{O}_{2} \mathrm{Na}\end{array}$ & 132 & 6 & $\begin{array}{l}313.2532 \\
295.2429 \\
271.2429 \\
247.1703 \\
233.1551 \\
217.1954 \\
203.1792 \\
187.1119 \\
177.1638\end{array}$ & $\begin{array}{l}\mathrm{C}_{20} \mathrm{H}_{34} \mathrm{ONa} \\
\mathrm{C}_{20} \mathrm{H}_{32} \mathrm{Na} \\
\mathrm{C}_{18} \mathrm{H}_{30} \mathrm{ONa} \\
\mathrm{C}_{14} \mathrm{H}_{24} \mathrm{O}_{2} \mathrm{Na} \\
\mathrm{C}_{13} \mathrm{H}_{22} \mathrm{O}_{2} \mathrm{Na} \\
\mathrm{C}_{14} \mathrm{H}_{26} \mathrm{Na} \\
\mathrm{C}_{13} \mathrm{H}_{24} \mathrm{Na} \\
\mathrm{C}_{11} \mathrm{H}_{16} \mathrm{ONa} \\
\mathrm{C}_{11} \mathrm{H}_{22} \mathrm{Na}\end{array}$ \\
\hline & 25.8 & 329.2481 & $\mathrm{C}_{22} \mathrm{H}_{33} \mathrm{O}_{2}$ & 38 & 7 & l & l \\
\hline & 25.1 & 301.2143 & $\mathrm{C}_{18} \mathrm{H}_{30} \mathrm{O}_{2} \mathrm{Na}$ & 61 & 4 & l & / \\
\hline Pan216 R2 & 21.8 & 294.0532 & $\mathrm{C}_{12} \mathrm{H}_{12} \mathrm{~N}_{3} \mathrm{O}_{4} \mathrm{~S}$ & 0 & 8 & $\begin{array}{l}259.0844 \\
230.0451\end{array}$ & $\begin{array}{c}? \\
\mathrm{C}_{12} \mathrm{H}_{8} \mathrm{NO}_{4}\end{array}$ \\
\hline
\end{tabular}

a Bold mass was further processed by MS/MS. 
A

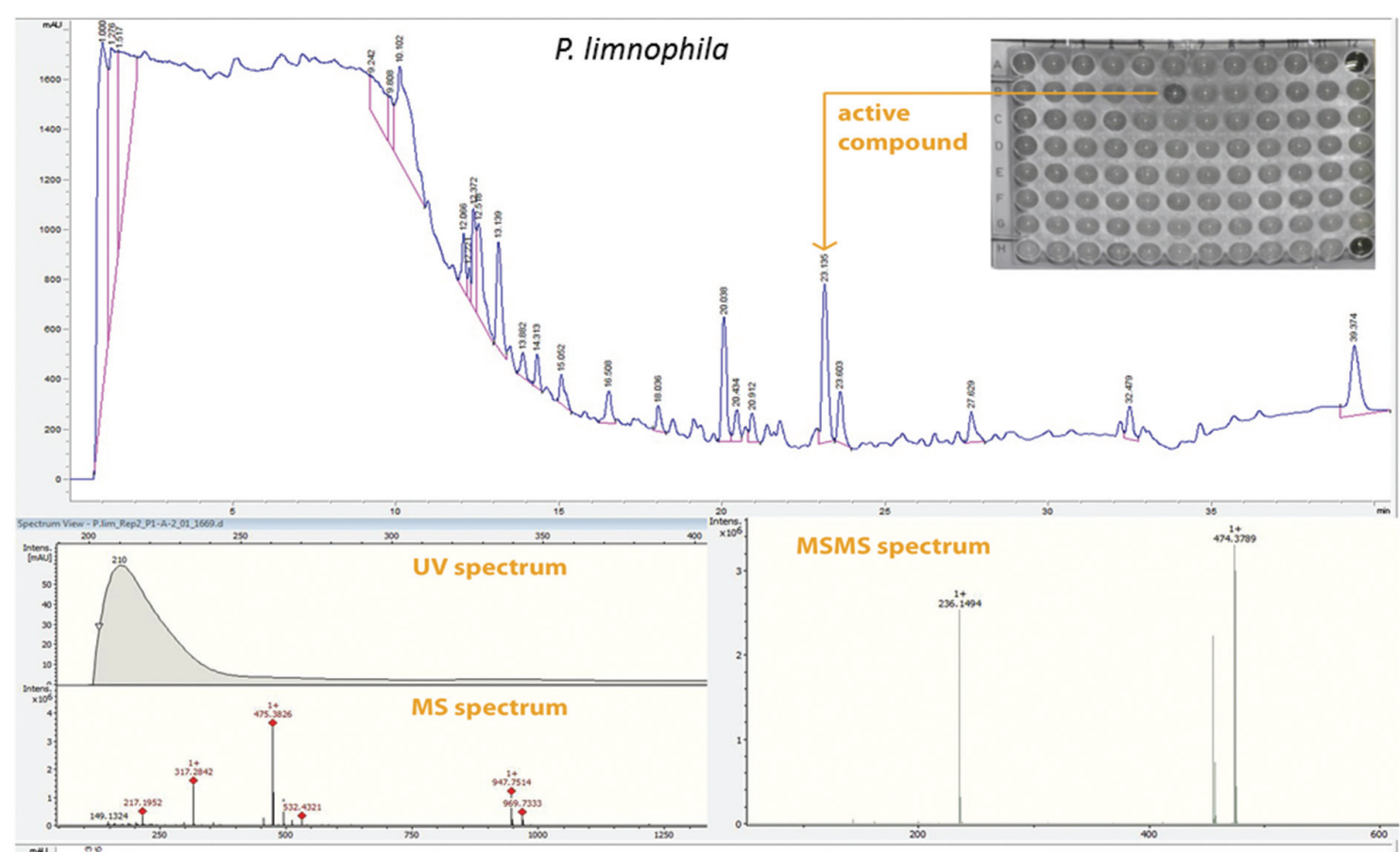

B
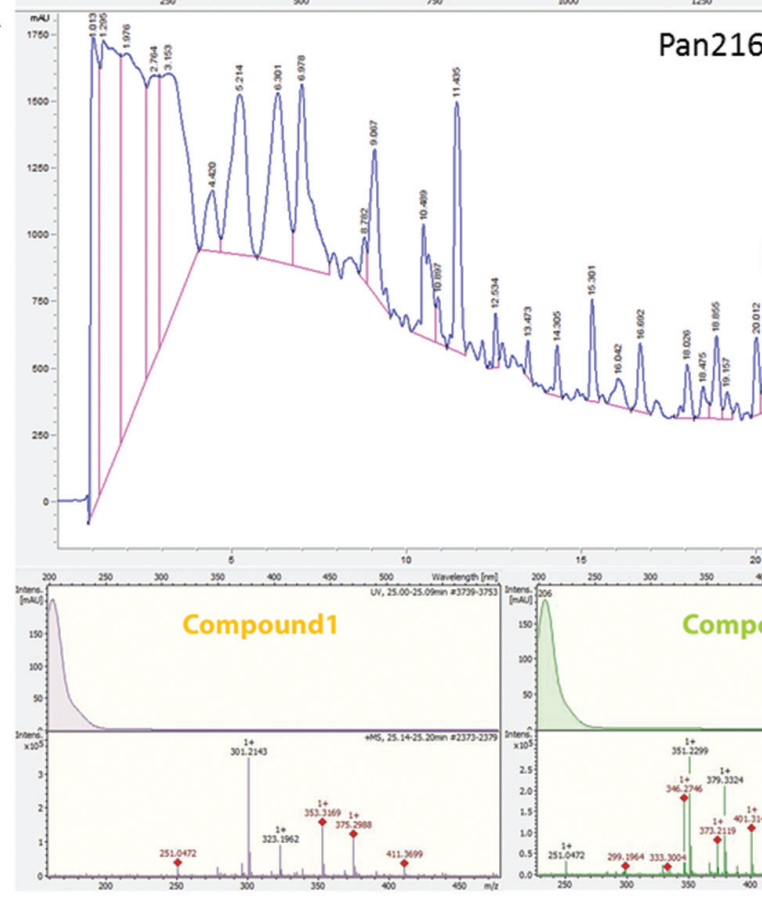

Pan216

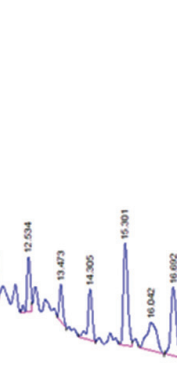

\section{6}
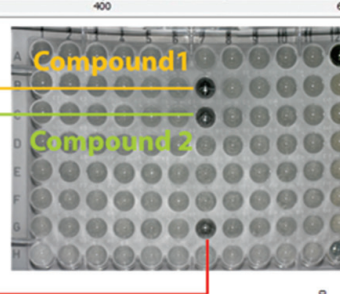

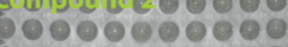

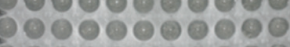

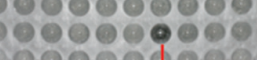
00000900000

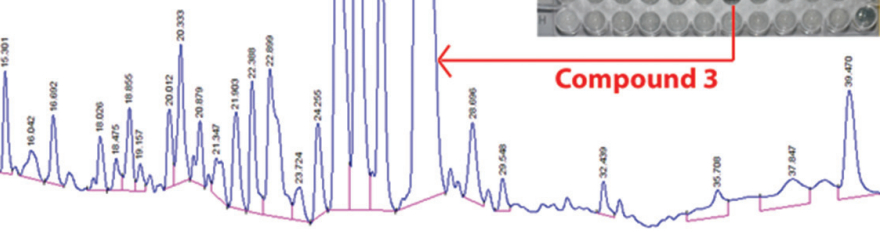


in the molecular ion cluster as the ${ }^{34} \mathrm{~S}$ isotope. However, the other possibilities for the molecular formula $\mathrm{C}_{13} \mathrm{H}_{12} \mathrm{NO}_{5} \mathrm{P}$ and $\mathrm{C}_{20} \mathrm{H}_{7} \mathrm{NO}_{2}$ cannot be excluded. In the ESIMS spectra in negative mode $[\mathrm{M}-\mathrm{H}]^{-}$respectively $[2 \mathrm{M}-\mathrm{H}]^{-}$peaks at 291.1 and 585.0 confirm the assignment. There is no known natural product included in the DNP for any of the three molecular formulae.

Thus we demonstrated a procedure to correlate HPLC peaks of planctomycetal extracts with antimicrobial activity that allows subsequent purification of the compound of interest. Initial data pointed towards novel bioactive molecules with antimicrobial activity produced by Planctomycetes.

\section{Cultivation of Planctomycetes in Process Controlled Bioreactors}

Thus far we have presented tools and procedures for the discovery of planctomycetal bioactive molecules, yet one important feature is missing if they are to be useful: large scale cultivation. Anammox Planctomycetes are routinely cultivated in different types of bioreactors in small, large and industry scale, mainly for waste water treatment (for review see, van Niftrik and Jetten, 2012). However, little to no experience exists with the planctomycetal orders Phycisphaerales and Planctomycetales. The known species belonging to the order Phycisphaerales have small genomes with few secondary metabolite related clusters while species of the order Planctomycetales were found to comprise large genomes with many secondary metabolite related genes (Jeske et al., 2013). Among Planctomycetales, only the cultivation of $R$. baltica in a small-scale custom-made chemostat was described thus far (Frank et al., 2011). However, such experiments were not performed with the intention to obtain secondary metabolites.

In this study, we developed the required media and procedures to cultivate both limnic ( $P$. limnophila) and marine ( $R$. baltica) Planctomycetes in a $10 \mathrm{l}$ bench-top bioreactor (BIOSTAT ${ }^{\circledR} \mathrm{B}$, Sartorius). Our protocols (see Materials and Methods) fit to batch (Figure 3) and fed-batch (Supplementary Figure S3) cultivation in different sized stirring tank reactors as our reactor system allows seamless scale-up, at least for up to 1001 .

First, we determined optimal growth conditions in maintain medium supplemented with glucose (Figures $\mathbf{3 A}, \mathbf{B}$ ) and obtained optimal biomass production, whereby the $\mathrm{pH}$ was kept constant at 7.5 for $R$. baltica and at 7.2 for P. limnophila. Since HEPES is used routinely to buffer planctomycetal culture media, the future scale-up might be limited by high costs of this chemical. Thus, we explored different buffer systems and found that at least the growth of P. limnophila is not affected by phosphate buffering (see Materials and Methods). Growth was measured by $\mathrm{OD}_{600}$ and dry weight, while glucose consumption was determined in addition (Figures 3A,B). While both curves, dry weight and $\mathrm{OD}_{600}$, comprise a similar shape for $R$. baltica, the slope of the $\mathrm{OD}_{600}$ curve for $P$. limnophila is steeper than the curve representing dry weight measurements.

Paralleling the extraction procedure employed for flask cultures, we added XAD to the bioreactor that was finally harvested with an analyze sieve prior to extraction. Thus, even for planctomycetal large-scale cultures our procedure allows small volume downstream processes, significantly reducing the amount of organic solvents and effort for the extraction process.

When two independent $P$. limnophila 51 cultivation batches were employed for XAD extraction and subsequent HPLC analysis, the resulting metabolite profiles differed slightly (Supplementary Figure S4). Eight minor peaks (red asterisks) and one major peak (black asterisks) occurred only in one of the two replicates, while only the three major peaks (black arrows) were found in both extracts.

Thus, we developed a large scale cultivation approach for aerobic Planctomycetes that reduces cost and effort but still lacks $100 \%$ reproducibility.

\section{DISCUSSION}

The aim of this pilot study was to develop the tools and procedures required to produce, isolate, and analyze secondary metabolites from Planctomycetes. We employed different marine and limnic Planctomycetes as a proof of principal for each step of our pipeline.

The first step was the development of cultivation conditions that support the production of secondary metabolites. To determine a suitable cultivation strategy, we took the ecology of Planctomycetes into account. It has been demonstrated by both us and others that Planctomycetes interact with phototrophs, such as cyanobacteria, in marine and limnic habitats and that the Planctomycetes can even dominate biofilms in these carbonrich ecological niches (Bengtsson and Øvreås, 2010; Bengtsson et al., 2010, 2012; Pizzetti et al., 2011a,b; Jeske et al., 2013). Due to the slow growth of Planctomycetes, we hypothesized that their dominance in biofilms could be due to production of antibiotics, which could provide an advantage over faster-growing bacteria. To elucidate whether environmental cues can trigger the production of secondary metabolites, we first developed both a limnic (MM1) and a marine (MM2) Maintain Medium (Figure 1). This development is vital, because it dramatically reduces the culture-media components in acetone extracts to zero (Supplementary Figure S2). Thus, the MM allows for easy detection and characterization of produced metabolites. In addition, changes in production of bioactive molecules caused by altered growth conditions could be easily monitored. Such alterations could, for example, be achieved by supplementing the MM with different carbon sources. Furthermore, ecomimetic experiments can replicate the environmental interactions of Planctomycetes and phototrophs in a chemically defined manner, allowing for determination of environmental cues which are currently unknown. In a proof of principle study we found that NAG, a main component of the cyanobacterial cell wall, altered the secreted secondary metabolome of both P. limnophila and $R$. baltica (Figure 2). This finding is not surprising, since it is wellknown that changes in the composition of cultivation media can affect the biosynthesis of secondary metabolites (Berdy, 2005). In the past, selection of growth media composition to stimulate the expression of 'silent' secondary metabolite genes or clusters was rather random. Here, we utilize the chemical characteristics of the planctomycetal ecological niche to guide alterations of 
the medium composition which led to the production of novel secondary metabolites. Algae and bacteria produce a multitude of different compounds and it has been shown by both our group and others that many of these molecules can be utilized by Planctomycetes (Wegner et al., 2012; Jeske et al., 2013). Thus, our Maintain Medium provides a base medium that allows for addition of many kinds of substrate combinations. Subsequent analysis of changes in the secondary metabolome can be correlated with environmental cues (substrates) present in the media. Furthermore, the addition of XAD adsorber resin allowed for easy and low solvent-volume extraction and analysis of such molecules.

After developing chemically defined growth conditions and ecomimetic, the second step in our pipeline is the screening for biological activity. We successfully evaluated agar plate diffusion, dual culture, and MIC assays and found all three methods very useful to screen Planctomycetes. An initial screen with the cheap and easy dual culture approach allows for determination of potential antibiotic producers, whilst the agar plate diffusion and the MIC assay allow for further purification of extracts and isolation of active components. Most importantly, we found evidence for antimicrobial activity of Planctomycetes against both Gram-negative and Gram-positive bacteria. This finding might support our hypothesis of the planctomycetal interaction with phototrophs.

The third step is the correlation of bioactivity in a crude extract with a particular HPLC peak. This step is crucial for isolation and purification of bioactive compounds, facilitating subsequent structure elucidation. We developed a comprehensive approach by combining analytical and preparative HPLC with direct fractionation of extracts into 96-well plates that can be subsequently employed for activity screening (Figure 4). While the elucidation of distinct structures is beyond the scope of this study we gained some insights into the chemical composition of planctomycetal antibiotic molecules. For example, in $P$. limnophila replicate $\# 2$, an active metabolite had a molecular formula of $\mathrm{C}_{26} \mathrm{H}_{51} \mathrm{NO}_{6}$, which is not present in the DNP, suggesting it could be a novel compound. Although de novo structure elucidation is impossible with MS/MS data alone, early indications can be obtained by fragmentation ions. For example, fragments of the aforementioned compound indicate that the structure consists of a long aliphatic chain and a heteroatom-containing core structure. Pan216 replicate \#2 contained an active metabolite with molecular formula of $\mathrm{C}_{12} \mathrm{H}_{11} \mathrm{~N}_{3} \mathrm{O}_{4} \mathrm{~S}$, this was also not in the DNP and suggests a new natural product. UV absorption maxima at 244 and $294 \mathrm{~nm}$ might indicate an aromatic or heteroaromatic residue. However, Pan 216 replicate \# 1 showed no evidence of this active metabolite. Three distinct metabolites inhibiting the growth of $B$. subtilis were also produced in $\mathrm{Pan} 216$ replicate \#2. The active metabolites had molecular formulae of $\mathrm{C}_{22} \mathrm{H}_{34} \mathrm{O}_{2}, \mathrm{C}_{22} \mathrm{H}_{32} \mathrm{O}_{2}$, and $\mathrm{C}_{18} \mathrm{H}_{30} \mathrm{O}_{2}$, which corresponds to 6,7 , and $4^{\circ}$ of unsaturation, respectively. Dozens of compounds are known for these molecular formulae and so we cannot identify these metabolites nor state that these metabolites are new.

Both the metabolome and the bioactivity varied strongly between the replicates of $P$. limnophila and strain Pan216, implying that the production of secondary metabolites is highly variable, responsible factors could include the inoculum, oxygenation, growth stage, formation of aggregates, as well as degradation of compounds during cultivation. Thus, this study revealed that single planctomycetal strains might be able to produce a multitude of antimicrobial secondary metabolites. Therefore, Planctomycetes do not only contain the gene clusters for secondary metabolite production, but actually produce compounds with antibacterial activity. However, structure elucidation of such bioactive molecules requires large scale cultivation of planctomycetal producer strains.

To facilitate future structure elucidation attempts, the last step of our pipeline is the cultivation of marine and limnic Planctomycetes in large scale stirring tank bioreactors. We choose a 51 volume in 101 computer controlled bioreactors as this allows for easy scale-up. While establishing the protocols we noticed a disparity between the approximate doubling times determined by $\mathrm{OD}_{600}(57 \mathrm{~h})$ and dry weight $(47 \mathrm{~h})$ for $P$. limnophila, and $\mathrm{OD}_{600}(62 \mathrm{~h})$ and dry weight $(41 \mathrm{~h})$ for $R$. baltica. Therefore, future experiments using dry weight instead of optical density might provide better correlation between growth phase and secondary metabolite production. Whilst HPLC analysis of crude extracts of two replicates of $51 \mathrm{P}$. limnophila batch cultures showed differences, the most prominent peaks were reproducible and would be the obvious candidates for structure elucidation. Once these prominent compounds have been determined, batch culture of $P$. limnophila may have to be further studied to enable isolation of the compounds which appear more variable in their production. It is possible that the life cycle switch of $P$. limnophila could cause fluctuations in the secondary metabolome (Jogler et al., 2011). P. limnophila daughter cells are flagellated and live as planktonic swimmers before developing into stalked sessile cells which are capable of dividing and forming biofilms (Jogler et al., 2011). If both cell types react to environmental cues in the same way remains unknown. The cultures used in our pilot study were not synchronized and thus the ratio between stalked sessile cells and flagellated swimmer cells might have varied among individual experiments. In addition, increased formation of cell aggregates might explain both the differences in production of secondary metabolites and the differences between $\mathrm{OD}_{600}$ and dry weight measurements. This is because aggregates give different $\mathrm{OD}_{600}$ values than single free-living cells. Despite such limitations, our approach will allow for the large scale production of planctomycetal compounds. For future studies, alternative reactor models and synchronization of cultures could increase reproducibility in the production of planctomycetal secondary metabolites.

In summary, we presented a pipeline for the utilization of Planctomycetes as sources of novel antibiotics. Screening of marine and limnic planctomycetal species demonstrated discovery of antimicrobial compounds. This finding further supports our hypothesis of allelopathic interactions between phototrophs and Planctomycetes, and emphasizes the usefulness of ecomimetic experiments to stimulate the production of bioactive molecules. This work will provide the starting point for the exploration of Planctomycetes as a currently untapped source of novel bioactive molecules. 


\section{AUTHOR CONTRIBUTIONS}

OJ and CJ designed the project. OJ and MK cultivated all required bacteria with the help from $\mathrm{MJ}$ and extracted crude extracts from planctomycetal cultures. MK, OJ, and FS performed HPLC analysis. MK performed bioreactor experiments and measurements of biomass and glucose consumption. OJ performed with the help of MK activity assays. FS and BF performed HPLC fractionation and mass spectra analysis. PR did phylogenetic analysis. OJ and CJ wrote the manuscript with the help from FS and JW and input from all other authors.

\section{ACKNOWLEDGMENTS}

We thank Birte Trunkwalter, Diana Telkemeyer, and Anja Heuer for skillful technical assistance, Prof. Dr. Marc Stadler for support, and Robert Barnett for proofreading the manuscript. This work was supported by the Leibniz Institute DSMZ and by the Deutsche Forschungsgemeinschaft (DFG joint grant SU 936/1-1 and JO 893/4-1).

\section{SUPPLEMENTARY MATERIAL}

The Supplementary Material for this article can be found online at: http://journal.frontiersin.org/article/10.3389/fmicb. 2016.01242

FIGURE S1 | Phylogenetic position of strain Pan216 within the phylum Planctomycetes. The 16S rRNA gene-based tree was reconstructed under the maximum likelihood criterion with 1000 bootstrap resamplings and rooted to a cluster of sequences from anammox Planctomycetes (not shown). Strains of interest (isolate Pan216, Planctopirus limnophila and Rhodopirellula baltica) are

\section{REFERENCES}

Bengtsson, M. M., and Øvreås, L. (2010). Planctomycetes dominate biofilms on surfaces of the kelp Laminaria hyperborea. BMC Microbiol. 10:261. doi: 10.1186/1471-2180-10-261

Bengtsson, M. M., Sjøtun, K., Lanzen, A., and Øvreås, L. (2012). Bacterial diversity in relation to secondary production and succession on surfaces of the kelp Laminaria hyperborea. ISME J. 6, 2188-2198. doi: 10.1038/ismej. 2012.67

Bengtsson, M. M., Sjøtun, K., and Øvreås, L. (2010). Seasonal dynamics of bacterial biofilms on the kelp Laminaria hyperborea. Aquat. Microb. Ecol. 60, 71-83. doi: 10.3354/ame01409

Berdy, J. (2005). Bioactive microbial metabolites. J. Antibiot. 58, 1-26. doi: 10.1038/ja.2005.1

Christie-Oleza, J. A., Piña-Villalonga, J. M., Bosch, R., Nogales, B., and Armengaud, J. (2012). Comparative proteogenomics of twelve Roseobacter exoproteomes reveals different adaptive strategies among these marine bacteria. Mol. Cell. Proteomics 11, M111013110. doi: 10.1074/mcp.m111.013110

Cooper, M. A., and Shlaes, D. (2011). Fix the antibiotics pipeline. Nature 472:32. doi: $10.1038 / 472032 \mathrm{a}$

Donadio, S., Monciardini, P., and Sosio, M. (2007). Polyketide synthases and nonribosomal peptide synthetases: the emerging view from bacterial genomics. Nat. Prod. Rep. 24, 1073-1109. doi: 10.1039/b514050c

Fowler, T., Walker, D., and Davies, S. C. (2014). The risk/benefit of predicting a post-antibiotic era: is the alarm working? Ann. N. Y. Acad. Sci. 1323, 1-10. doi: $10.1111 /$ nyas. 12399 highlighted in black and bold-faced. Validly published planctomycetal type strains are indicated by gray font and serve as matrix to pronounce the distinct phylogenetic position of strain Pan216. To estimate reliability of the tree branches, maximum parsimony and neighbor joining phylogenetic trees (not shown) were calculated (1000 bootstrap resamplings) and branch support was compared to the maximum likelihood phylogenetic tree. Black dots express bootstrap support values $>70 \%$, gray dots express support values $>50 \%$ but $<70 \%$.

FIGURE S2 | High performance liquid chromatography analysis of the marine and limnic cultivation media for Planctomycetes. (A) Full medium M1 for limnic Planctomycetes shows high signal peaks after a retention time from 3 to 10 min (intensity up to $8 \times 10^{5} \mathrm{Au}$ ). (B) The chemically defined MM 1 shows no detectable signal peaks compared to its full medium M1. (C) Full medium M2 for marine Planctomycetes shows high signal peaks after retention time from 20 to 50 min (intensity up to $4 \times 10^{5} \mathrm{Au}$ ). (D) The chemically defined MM2 shows no detectable signal peaks compared to $\mathrm{M} 2$

FIGURE S3 | Dry weight determination of $P$. limnophila cells over 17 days of cultivation in $\mathbf{5}$ I fermentation with NAG. The dry weight of $P$. limnophila cells increased from $0.6 \mathrm{~g} / \mathrm{l}$ volume to $2.9 \mathrm{~g} / \mathrm{l}$ volume after 17 days cultivation. The culture was fed after 7 days with $25 \mathrm{ml} \mathrm{NAG}$ and $10 \mathrm{ml}$ vitamin solution (red arrow). This demonstrates that a similar dry-weight could be achieved with NAG as sole carbon source if a fed- batch procedure is employed.

FIGURE S4 | Reproducibility of the HPLC spectra of two distinct P. limnophila methanol extracts of 5 I fermentation. In both HPLC spectra of the two distinct extracts similar signal peaks could be detected with slight shifts in retention time and intensity but also differences could be observed. Eight minor peaks (red asterisks) and one major peak (black asterisks) occurred only in one of the two replicates, while only the three major peaks (black arrows) were found in both extracts. The HPLC spectrum of the first extract (green curve) showed the first signal peak after, $7 \mathrm{~min}$ and a second after $15 \mathrm{~min}$ but no peak at $10 \mathrm{~min}$ while the HPLC spectrum of the second run (purple curve) showed the first peak at 10 but not after 7 or $15 \mathrm{~min}$. The HPLC spectrum of the second extract revealed six signal peaks after a retention time of 25-32 min and an intensity of $1.56 \times 10^{5} \mathrm{Au}$ up to $10^{6} \mathrm{Au}$. In the first extract an additional signal peak at $24 \mathrm{~min}$ was detected, the intensity of the signal peak at 25 min decreased from $10^{6} \mathrm{Au}$ to $9 \times 10^{5} \mathrm{Au}$, while the peaks at 26 and 27 min were absent. A further additional signal peak in the HPLC spectrum of the first extract was detected at 52 min that was absent in the analysis of the second extract.

Frank, C. S., Langhammer, P., Fuchs, B. M., and Harder, J. (2011). Ammonium and attachment of Rhodopirellula baltica. Arch. Microbiol. 193, 365-372. doi: 10.1007/s00203-011-0681-1

Fuerst, J. A., and Sagulenko, E. (2011). Beyond the bacterium: planctomycetes challenge our concepts of microbial structure and function. Nat. Rev. Microbiol. 9, 403-413. doi: 10.1038/nrmicro2578

Gade, D., Stührmann, T., Reinhardt, R., and Rabus, R. (2005). Growth phase dependent regulation of protein composition in Rhodopirellula baltica. Environ. Microbiol. 7, 1074-1084. doi: 10.1111/j.1462-2920.2005. 00784.x

Glöckner, F. O., Kube, M., Bauer, M., Teeling, H., Lombardot, T., Ludwig, W., et al. (2003). Complete genome sequence of the marine planctomycete Pirellula sp. strain 1. Proc. Natl. Acad. Sci. U.S.A. 100, 8298-8303. doi: 10.1073/pnas.1431443100

Jeske, O., Jogler, M., Petersen, J., Sikorski, J., and Jogler, C. (2013). From genome mining to phenotypic microarrays: planctomycetes as source for novel bioactive molecules. Antonie Van Leeuwenhoek 104, 551-567. doi: 10.1007/s10482-0130007-1

Jeske, O., Schüler, M., Schumann, P., Schneider, A., Boedeker, C., Jogler, M., et al. (2015). Planctomycetes do possess a peptidoglycan cell wall. Nat. Commun. 6:7116. doi: $10.1038 /$ ncomms8116

Jogler, C., Glöckner, F. O., and Kolter, R. (2011). Characterization of Planctomyces limnophilus and development of genetic tools for its manipulation establish it as a model species for the phylum Planctomycetes. Appl. Environ. Microbiol. 77, 5826-5829. doi: 10.1128/AEM.05132-11

Jogler, C., Waldmann, J., Huang, X., Jogler, M., Glöckner, F. O., Mascher, T., et al. (2012). Identification of proteins likely to be involved in morphogenesis, cell 
division, and signal transduction in Planctomycetes by comparative genomics. J. Bacteriol. 194, 6419-6430. doi: 10.1128/JB.01325-12

Jogler, M., and Jogler, C. (2013). "Towards the development of genetic tools for Planctomycetes," in New Models for Cell Structure, Origins and Biology: Planctomycetes, ed. J. A. Fuerst (Heidelberg: Springer).

Lage, O. M., and Bondoso, J. (2014). Planctomycetes and macroalgae, a striking association. Front. Microbiol. 5:267. doi: 10.3389/fmicb.2014. 00267

Lane, D. J. (ed.) (1991). 16S/23S rRNA Sequencing. Chichester: Wiley.

Lee, K. C., Webb, R. I., and Fuerst, J. A. (2009). The cell cycle of the planctomycete Gemmata obscuriglobus with respect to cell compartmentalization. BMC Cell. Biol. 10:4. doi: 10.1186/1471-2121-10-4

Ludwig, W., Strunk, O., Westram, R., Richter, L., Meier, H., Yadhukumar, et al. (2004). ARB: a software environment for sequence data. Nucleic Acids Res. 32, 1363-1371. doi: 10.1093/nar/gkh293

Morris, R. M., Longnecker, K., and Giovannoni, S. J. (2006). Pirellula and OM43 are among the dominant lineages identified in an Oregon coast diatom bloom. Environ. Microbiol. 8, 1361-1370. doi: 10.1111/j.1462-2920.2006. 01029.x

Müller, R., and Wink, J. (2014). Future potential for anti-infectives from bacteria how to exploit biodiversity and genomic potential. Int. J. Med. Microbiol. 304, 3-13. doi: 10.1016/j.ijmm.2013.09.004

Pilhofer, M., Rappl, K., Eckl, C., Bauer, A. P., Ludwig, W., Schleifer, K. H., et al. (2008). Characterization and evolution of cell division and cell wall synthesis genes in the bacterial phyla Verrucomicrobia, Lentisphaerae, Chlamydiae, and Planctomycetes and phylogenetic comparison with rRNA genes. J. Bacteriol. 190, 3192-3202. doi: 10.1128/JB.01797-07

Pizzetti, I., Fuchs, B. M., Gerdts, G., Wichels, A., Wiltshire, K. H., and Amann, R. (2011a). Temporal variability of coastal Planctomycetes clades at kabeltonne station, North Sea. Appl. Environ. Microbiol. 77, 5009-5017. doi: 10.1128/AEM.02931-10

Pizzetti, I., Gobet, A., Fuchs, B. M., Amann, R., and Fazi, S. (2011b). Abundance and diversity of Planctomycetes in a Tyrrhenian coastal system of central Italy. Aquat. Microb. Ecol. 65, 129-141. doi: 10.3354/ame01535

Pruesse, E., Peplies, J., and Glöckner, F. O. (2012). SINA: accurate high-throughput multiple sequence alignment of ribosomal RNA genes. Bioinformatics 28, 18231829. doi: 10.1093/bioinformatics/bts252
Strous, M., Heijnen, J. J., Kuenen, J. G., and Jetten, M. S. M. (1998). The sequencing batch reactor as a powerful tool for the study of slowly growing anaerobic ammonium-oxidizing microorganisms. Appl. Microbiol. Biotechnol. 50, 589596. doi: $10.1007 / \mathrm{s} 002530051340$

Tekniepe, B. L., Schmidt, J. M., and Starr, M. P. (1981). Life cycle of a budding and appendaged bacterium belonging to morphotype IV of the Blastocaulis-Planctomyces group. Curr. Microbiol. 5, 1-6. doi: 10.1007/BF0156 6588

van Niftrik, L., and Jetten, M. S. (2012). Anaerobic ammonium-oxidizing bacteria: unique microorganisms with exceptional properties. Microbiol. Mol. Biol. Rev. 76, 585-596. doi: 10.1128/MMBR.05025-11

van Teeseling, M. C., Mesman, R. J., Kuru, E., Espaillat, A., Cava, F., Brun, Y. V., et al. (2015). Anammox Planctomycetes have a peptidoglycan cell wall. Nat. Commun. 6:6878. doi: 10.1038/ncomms7878

Wegner, C. E., Richter-Heitmann, T., Klindworth, A., Klockow, C., Richter, M., Achstetter, T., et al. (2012). Expression of sulfatases in Rhodopirellula baltica and the diversity of sulfatases in the genus Rhodopirellula. Mar. Genomics 9, 51-61. doi: 10.1016/j.margen.2012.12.001

Wilson, M. C., Mori, T., Ruckert, C., Uria, A. R., Helf, M. J., Takada, K., et al. (2014). An environmental bacterial taxon with a large and distinct metabolic repertoire. Nature 506, 58-62. doi: 10.1038/nature12959

Zhao, J., Yang, N., and Zeng, R. (2008). Phylogenetic analysis of type I polyketide synthase and nonribosomal peptide synthetase genes in Antarctic sediment. Extremophiles 12, 97-105. doi: 10.1007/s00792-0070107-9

Conflict of Interest Statement: The authors declare that the research was conducted in the absence of any commercial or financial relationships that could be construed as a potential conflict of interest.

Copyright @ 2016 Jeske, Surup, Ketteniß, Rast, Förster, Jogler, Wink and Jogler. This is an open-access article distributed under the terms of the Creative Commons Attribution License (CC BY). The use, distribution or reproduction in other forums is permitted, provided the original author(s) or licensor are credited and that the original publication in this journal is cited, in accordance with accepted academic practice. No use, distribution or reproduction is permitted which does not comply with these terms. 